\title{
A Response to the Study "Lifestyle Counseling for Medication Adherence in Glaucoma" [Letter]
}

\section{Lois Crabtree $\mathbb{D}$}

Epsom and St Helier University Hospitals, Epsom, UK
Correspondence: Lois Crabtree Epsom and St Helier University Hospitals, Epsom, UK

Email loiscrabtree@hotmail.co.uk; lois. crabtreel@nhs.net

\section{Dear editor}

Thank you to the authors of the study "Lifestyle Counseling for Medication Adherence in Glaucoma" for an interesting perspective on how to increase adherence to glaucoma medications. ${ }^{1}$

In this study, the authors note that there was no statistically significant difference in education status between adherent and non-adherent patients. However, previous literature has found a significant association between low literacy levels and poor adherence to medical treatment. This association has been evidenced in a study focusing on glaucoma medication adherence, and extends to other medical specialties including diabetic medications. ${ }^{2,3}$

In the United States of America $42 \%$ of the population have some form of a college degree. ${ }^{4}$ Within the population studied in this article, $70 \%$ of the 116 patients were college graduates. This poses a potential overestimation of the educational ability of patients when applying the results to the general population.

If the study participants chosen were representative of the levels of education within the general population, a statistically significant difference may have been discovered. This is an important study limitation to note, as underestimating the link between health literacy and medication adherence may compound health inequalities.

The study reports that patients were sent home with printed educational materials. Research has shown that the majority of ophthalmology based patient education materials are written at a level too difficult for the general population to understand. ${ }^{5}$ Health literacy must be considered if providing written and/or verbal counseling to improve glaucoma medication adherence in the general patient population. This will help ensure the information is understandable and accessible to all.

\section{Disclosure}

The author reports no conflicts of interest in this communication.

\section{References}

1. Kim S, Tong B, Lee J, Borodge D, Kooner K. Lifestyle counseling for medication adherence in glaucoma. Clin Ophthalmol. 2021;15:3521-3529. doi:10.2147/OPTH.S321351

2. Muir KW, Santiago-Turla C, Stinnett SS, et al. Health literacy and adherence to glaucoma therapy. Am J Ophthalmol. 2006;142(2):223-226.e2. doi:10.1016/j.ajo.2006.03.018 
3. Schillinger D, Grumbach K, Piette J, et al. Association of health literacy with diabetes outcomes. $J$ Am Med Assoc. 2002;288 (4):475-482. doi:10.1001/jama.288.4.475

4. Census - Table Results [Internet]; [cited December 10, 2021]. Available from: https://data.census.gov/cedsci/table?t= EducationalAttainment\&g=0100000US\%2404000\%24001\&y= 2019\&tid=ACSST1Y2019.S1501. Accessed December 16, 2021.
5. Williams AM, Muir KW, Rosdahl JA. Readability of patient education materials in ophthalmology: a single-institution study and systematic review. BMC Ophthalmol. 2016;16(1):1-11. doi:10.1186/ s12886-016-0315-0

Dove Medical Press encourages responsible, free and frank academic debate. The content of the Clinical Ophthalmology 'letters to the editor' section does not necessarily represent the views of Dove Medical Press, its officers, agents, employees, related entities or the Clinical Ophthalmology editors. While all reasonable steps have been taken to confirm the content of each letter, Dove Medical Press accepts no liability in respect of the content of any letter, nor is it responsible for the content and accuracy of any letter to the editor

\section{Publish your work in this journal}

Clinical Ophthalmology is an international, peer-reviewed journal covering all subspecialties within ophthalmology. Key topics include: Optometry; Visual science; Pharmacology and drug therapy in eye diseases; Basic Sciences; Primary and Secondary eye care; Patient Safety and Quality of Care Improvements. This journal is indexed on PubMed

Submit your manuscript here: https://www.dovepress.com/clinical-ophthalmology-journal
Central and CAS, and is the official journal of The Society of Clinical Ophthalmology (SCO). The manuscript management system is completely online and includes a very quick and fair peer-review system, which is all easy to use. Visit http://www.dovepress.com/ testimonials.php to read real quotes from published authors. 